\title{
PII 0271-5198(96)00043-2
}

\section{ANNOUNCEMENT}

\section{$10^{\text {th }}$ EUROPEAN CONFERENCE ON CLINICAL HAEMORHEOLOGY}

\section{Lisbon (Portugal) 29 June-2 July 1997}

The European Society for Clinical Haemorheology (ESCH), Federation of European Societies, organises an European Conference every two years. For the first time such meeting will by held in Portugal, in the Calouste Gulbenkian Foundation Centre, Lisbon.

The Scientific Program is scheduled from 30 June to 2 July 1997.Registration and the opening ceremony will take place in 29 June.

Clinical haemorheology became a part of a vast and multidisciplinary scientific field, including the main interactions between blood flow and adjacent tissues.

The increasingly growth of knowledge and clinical implications to the care of different circulatory, vascular and systemic human problems may justify the leading position of clinical haemorheology on emergence of the vascular medicine.

Thus, blood flow and intravascular deformation, structural and functional properties of the vascular endothelium, the modulation of the vascular tone, the circulatory convey of oxygen and nutrients for all body tissues, the consequence of interactions between blood and extracellular matrix tissues to local and systemic body functions and homeostasis, are a few working areas of great scientific interest and clinical repercussions, to be developed in the $10^{\text {th }}$ European Conference on Clinical Haemorheology. In such event the enthusiastic participation of colleagues from all national societies and groups of haemorheology and akin scientific areas, will be the guarantee of expected success.

The Executive Board of the ESCH, the Local Organizing Committee and I look forward to your participation in Lisbon, next 1997. 


\section{0th European Conference \\ on Clinical Haemorheology}

Venue: Lisbon (Portugal) - 29 June, 1 and 2 July 1997

Organization: Portuguese Society for Haemorheology and Microcirculation.

Topics: Open io proposal from all national sucicties and groups.

Secretariat: SPHM, Apartado 4098 - 1502 Lisboa Codex - Portugal

\section{PRE-REGISTRATION FORM}

Please fill out this from and retum to Viagens Abreu, S.A.

C/o Mr. Rolf Dahmer - Congress Department

Edificio Abreu, Av. 25 de Abril, $n^{\circ} 2$

2795 Linda-a-Velha - PORTUGAL

Tel. 35114167200 - Fax. 35114143058

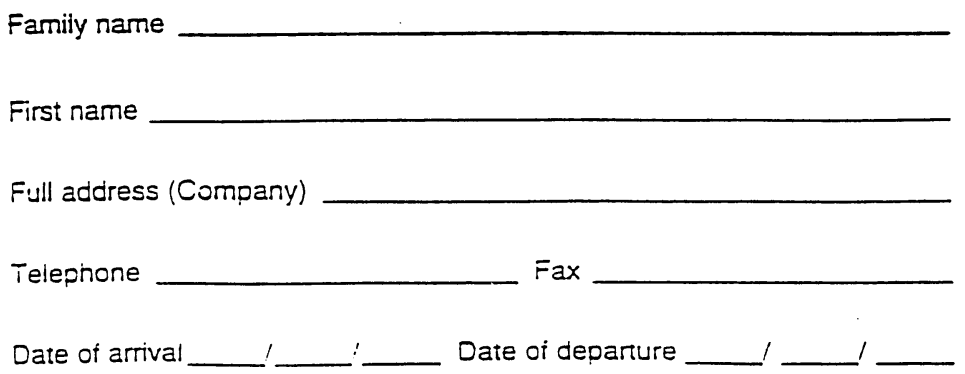

